\title{
PENGARUH GERAKAN LITERASI SEKOLAH TERHADAP MINAT BACA DAN HASIL BELAJAR BAHASA INDONESIA PADA SISWA KELAS IV SD NEGERI I PENATIH
}

\author{
N.M. Rusniasa ${ }^{1}$, N. Dantes $^{2}$, N.K. Suarni ${ }^{3}$ \\ ${ }^{123}$ Program Studi Pendidikan Dasar \\ Universitas Pendidikan Ganesha \\ Singaraja, Indonesia \\ e-mail: rusniasa@undiksha.ac.id ${ }^{1}$, dantes@undiksha.ac.id ${ }^{2}$, \\ niketut.suarni@undiksha.ac.id ${ }^{3}$
}

\begin{abstract}
Abstrak
Penelitian ini bertujuan untuk mengetahui pengaruh Gerakan Literasi Sekolah (GLS) terhadap minat baca dan hasil belajar Bahasa Indonesia pada siswa kelas IV SD Negeri I Penatih Tahun Pelajaran 2019/2020. Jenis penelitian ini adalah penelitian eksperimen semu dengan rancangan The Posttest-Only Control-Group Desain. Populasi penelitian adalah seluruh siswa kelas IV SD Negeri I Penatih Tahun Pelajaran 2019/2020 sebanyak 64 orang siswa. Dalam penentuan sampel dilakukan dengan menggunakan teknik random sampling, didapatkan bahwa: kelas IV A sebagai kelompok eksperimen, sedangkan kelas IV B sebagai kelompok kontrol. Data minat baca dikumpulkan dengan kuesioner dan hasil belajar Bahasa Indonesia menggunakan tes pilihan ganda. Data dianalisis menggunakan analisis Manova berbantuan SPSS 17.00 for windows. Hasil penelitian menunjukkan bahwa: Pertama,terdapat pengaruh yang signifikan Gerakan Literasi Sekolah (GLS) terhadap minat baca Bahasa Indonesia pada siswa kelas IV SD Negeri I Penatih Kecamatan Denpasar Timur Tahun Pelajaran 2019/2020. Kedua,terdapat pengaruh yang signifikan Gerakan Literasi Sekolah (GLS) terhadap hasil belajar Bahasa Indonesia pada siswa kelas IV SD Negeri I Penatih Kecamatan Denpasar Timur Tahun Pelajaran 2019/2020. Dan ketiga, terdapatpengaruh yangsignifikan Gerakan Literasi Sekolah (GLS) terhadap minat baca dan hasil belajar Bahasa Indonesia pada siswa kelas IV SD Negeri I Penatih Kecamatan Denpasar Tahun Pelajaran 2019/2020.
\end{abstract}

Kata Kunci : GLS; Hasil Belajar; Minat Baca

\begin{abstract}
This study aims to determine the effect of the School Literacy Movement on interest in reading and learning outcomes of Indonesian Language in grade IV students of SD Negeri I Penatih 2019/2020 Academic Year. This research is a quasi-experimental study with The Posttest-Only Control-Group Design. The study population was all students in grade IV Elementary School I Teacher for 2019/2020 Academic Year, 64 students. In determining the sample is done by using random sampling techniques, it was found that: class IV A as the experimental group, while class IV B as the control group. Data on reading interest was collected by questionnaire and students' learning outcomes in Indonesian used a multiple choice test. Data were analyzed using Manova analysis assisted by SPSS 17.00 for windows. The results showed that: First, there was a significant influence on the School Literacy Movement on the interest in reading Indonesian in grade IV students of SD Negeri I Penatih, East Denpasar District, 2019/2020 Academic Year. Second, there is a significant influence on the School Literacy Movement on the learning outcomes of Indonesian Language in fourth grade students of SD Negeri I Penatih Timur Denpasar District in 2019/2020 Academic Year. And thirdly, there is a significant influence on the School Literacy Movement on interest in reading and learning outcomes in Indonesian Language in grade IV students of SD Negeri I Penatih Denpasar District in 2019/2020 Academic Year.
\end{abstract}

Keywords : School Literacy Movement; Learning Outcomes; Interest In Reading 


\section{PENDAHULUAN}

Pada era digitalisasi ini, minat baca masyarakat sangat rendah. Hampir semua hal bisa divisualisasikan menjadi grafis sehingga mengurangi minat baca masyarakat. Contohnya ketika sebuah novel fiksi remaja yang dijadikan film layar lebar,kebanyakan remaja lebih menyukai menonton filmnya tanpa membaca novelnya. Hal tersebut dikarenakan efisien waktu dimana mereka bisa memahami isi cerita hanya memerlukan waktu sekitar 1,5-2 jam dengan menonton, daripada membaca novel tersebut berhari-hari. Tetapi ada beberapa hal yang tidak bisa digrafiskan begitu saja seperti mempelajari ilmu pengetahuan. Hal itu tidak bisa dimengerti ketika menontonnya, melainkan perlu membaca berulangulang bahkan harus mempraktikannya agar apa yang dibaca bisa dipahami.

Berbagai penelitian telah dilakukan untuk mengetahui minat baca diberbagai Negara. Dalam penelitian Anjani, dkk (2019; 5) dinyatakan bahwa: Program for International Student Assesment (PISA) menyebutkan tingkat literasi Indonesia pada tahun 2015 masih berada pada urutan ke 64 dari 72 negara. Dan data terbaru dari Most Littered Nation In The World yang dilakukan oleh Central Connecticut State University pada maret 2016, menunjukkan bahwa Indonesia berada pada urutan ke 60 dari 61 negara anggota riset. Sedangkan pada data statistik UNESCO 2012 menunjukkan indeks minat baca di Indonesia baru 0,001 . Artinya tiap 1.000 penduduk hanya satu orang saja yang mempunyai minat baca. Menurut indeks pembangunan pendidikan UNESCO ini, Indonesia berada di nomor 69 dari 127 negara.

Rendahnya minat baca merupakan permasalahan yang harus diatasi. Adapun langkah-langkah yang harus ditempuh untuk mengatasi permasalahan rendahnya minat baca ini adalah dengan mengoptimalkan gerakan literasi pada siswa di Sekolah Dasar. Untuk mengatasi masalah rendahnya minat baca. Peran orang tua dan lingkungan keluarga sangat dibutuhkan. Mereka dapat berpartisipasi dalam menumbuhkan minat baca putra- putrinya dengan memberikan hadiah berupa buku-buku bacaan pada hari-hari yang bersejarah bagi anak seperti memberikan buku cerita untuk kado kado ulang tahun, kemudian menemani anakanaknya membaca buku atau membacakan dongeng kepada anakanaknya. Dukungan guru juga sangat dibutuhkan, dalam meningkatkan minat baca. Upaya yang dapat dilakukan oleh guru antara lain menyiapkan pojok baca dan mengganti buku-buku setiap saat sehingga anak merasa tertarik untuk membaca. Membaca merupakan proses pelibatan seluruh aktivitas dan kemampuan berpikir siswa dalam memahami dan mereproduksi sebuah wacana tertulis (Abidin, dkk, 2017: 172).

Kementerian Pendidikan dan Kebudayaan mengembangkan Gerakan Literasi Sekolah (GLS) untuk mewujudkan sekolah sebagai organisasi pembelajaran (Kemendikbud, 2016).GLS adalah gerakan yang melibatkan semua warga sekolah (guru, peserta didik, orangtua/wali murid) dan masyarakat, sebagai bagian dari penyelenggara pendidikan. Program ini dilaksanakan untuk meningkatkan minat dan keterampilan membaca peserta didik, agar pengetahuan dikuasai secara lebih baik. Muatan GLS berisi tentang nilai-nilai budi pekerti, berupa kearifan lokal, nasional, dan global yang disampaikan sesuai dengan jenjang pendidikan siswa. Program GLS ini tidak hanya ditujukan untuk siswa. Program ini juga menuntut guru menjadi teladan dalam membaca.

Penyelenggaraan GLS ditujukan pada jenjang pendidikan sekolah dasar. Siswa pada jenjang sekolah dasar umumnya berusia pada kisaran 7-11 tahun. Dalam teori perkembangan intelektual Piaget, anak usia 7-11 Tahun berada pada tahap operasional konkret dimana anak sudah mulai memahami bagian materi yang diajarkan misalnya: bangun ruang dan jumlah; serta memiliki kemampuan memahami cara mengkombinasikan beberapa golongan benda yang tingkatannya bervariasi (Dantes, 2017:33). Guru sebagai pembimbing proses pembelajaran harus 
mampu memahami anak didik sebagai individu yang memiliki beragam, dan ciri yang unik (Dantes, 2017: 57). Dengan demikian, seorang guru dikehendaki secara kreatif harus dapat mengembangkan materi ajar yang sesuai dengan kebutuhan dan perkembangan anak didik dengan pengembangan professional guru dalam hal literasi di semua mata pelajaran.

Literasi merupakan kemampuan yang berkaitan dengan kegiatan membaca, berpikir, dan menulis yang bertujuan untuk meningkatkan kemampuan memahami informasi secara kritis, kreatif, dan reflektif. Suyono dan Hariyanto (2011:44) menyatakan bahwa literasi sebagai basis pengembangan pembelajaran efektif dan produktif memungkinkan siswa terampil mencari dan mengolah informasi yang sangat dibutuhkan dalam kehidupan berbasis ilmu pengetahuan di abad ke-21. Pembelajaran abad ke 21 bertumpu pada kemampuan literasi berbasis pada sain dan teknologi yang berlandaskan karakter, harkat, dan martabat kemanusiaan yang kuat (Dantes, 2017).

Keberadaan perpustakaan sekolah merupakan kunci keberhasilan dalam pelaksanaan GLS.Penataan ruang perpustakaan dan pemajangan buku-buku perpustakaan akan menentukan keberhasilan Gerakan Literasi Sekolah, Kondisi perpustakaan yang nyaman akan membawa siswa menikmati setiap bacaan yang dibaca dari buku-buku yang di pajang di ruang perpustakaan.

Kalida dan Mursyid (2015:38)

menjelaskan bahwa sekolah dan perpustakaan adalah satu-kesatuan yang tidak dapat dipisahkan. Selaras d engan itu, Kemendikbud (2016:16) menjelaskan fungsi perpustakaan adalah sebagai pusat pengelolaan pengetahuan dan sumber belajar di sekolah. Perpustakaan SD idealnya berperan dalam mengkoordinasikan pengelolaan pojok baca kelas, area baca, dan prasarana literasi lain di SD. Perpustakaan tak lagi sekadar tempat membaca dan meminjam buku. Lebih dari itu, menjadi pusat belajar dan interaksi siswa yang ingin maju melalui beragam kegiatan literasi, di antaranya mengarang, bedah buku.

Salah satu peneliti tentang GLS yaitu Faradina, (2017) menjelaskan GLS dapat dilakukan dengan mengembangkan pojok baca pada setiap kelas dengan penataan buku-buku semenarik mungkin yang bertujuan untuk menarik minat baca siswa. Buku yang dipajang di pojok baca dapat diperoleh dari sumbangan siswa, peminjaman buku dari perpustakaan, pemasangan poster-poster dan karya siswa, pemanfaatan ruang-ruang yang memungkinkan untuk memajang bahan kaya bacaan, ruang tunggu, UKS, kantin sekolah, serambi, area parkir, kebun sekolah dan tempat-tempat yang ada di lingkungan sekolah sehingga tercipta lingkungan kaya bacaan. Pengembangan minat baca siswa dapat dimulai dari perpustakaan dengan menyediakan bahan kaya bacaan dan penyedia sebagai media literasi dan area baca sehingga menciptakan lingkungan kaya bacaan. Selain dengan memanfaatkan pojok baca pelaksanaan GLS di Sekolah Dasar dapat dilakukan dengan memajang posterposter dan hasil karya siswa pada tempattempat yang strategi seperti memanfaatkan ruang Usaha Kesehatan Sekolah yaitu dengan memasang gambargambar dan tulisan-tuluisan yang memberikan pembelajaran pada siswa tentang pentingnya kesehatan. Penumbuhan minat baca siswa dapat pula dilakukan dengan memanfaatkan beranda sekolah, ruang toilet, halaman sekolah ruang guru dan kepala sekolah, kantin, serta tempat-tempat yang strategi yang ada di sekolah. Kegiatan yang menunjang GLS disekolah Dasar dapat dilakukan dengan mengaktivkan peserta didik pada bidang kegiatan yang mengacu pada penumbuhan budi pekerti dengan mengadakan lomba-lomba pada Bulan Bahasa seperti lomba mengarang cerita kepahlawanan, kesehatan, dan tema cerita lainnya. Koleksi buku di pojok baca dapat diperoleh dari buku-buku perpustakaan atau sumbangan dari siswa. Berdasarkan buku panduan Gerakan Literasi Sekolah di Sekolah Dasar yang diterbitkan pada Tahun 2016 
oleh Direktorat Jenderal Pendidikan Dasar dan Menengah Kementerian Pendidikan dan Kebudayaan, dijelaskan bahwa pelaksanaan program Gerakan Literasi Sekolah dengan bertahap pertama tahap pembiasaan pada tahap ini kecintaan pada bacaan perlu ditingkatkan agar minat bacanya meningkat bertujuan untuk menumbuhkan minat siswa terhadap bacaan. Kegiatan yang dilakukan pada tahap ini lebih banyak mengarah pada membaca dan menyimak. Tahap kedua yaitu pengembangan pada tahap ini kegiatan yang dilakukan adalah membaca, menulis, bercerita, menyampaikan informasi, dengan tujuan untuk bertujuan untuk mempertahankan minat baca. Tahap ketiga adalah tahap pembelajaran pada tahap pembelajaran, bertujuan untuk mempertahankan minat peserta didik terhadap bacaan dan terhadap kegiatan membaca, serta meningkatkan kecakapan literasi siswa melalui buku-buku pengayaan dan buku teks pelajaran. Kegiatan literasi pada tahap pembelajaran bertujuan mengaktifkan kemampuan membaca, menulis, berbicara.

Salah satu peneliti tentang GLS adalah Faradina (2017) yakni tentang pengaruh program gerakan literasi sekolah terhadap minat baca siswa di SD Islam terpadu muhammadiyah An-Najah Jatinom Klaten. Hasil penelitian tersebut menyatakan bahwa pengaruh program gerakan literasi sekolah terhadap minat baca siswa signifikan dan hambatan terjadi pada membaca dalam hati dan membaca nyaring. Dan hambatan terjadi pada pemberian hadiah untuk siswa peminjam buku terbayak, karena Sarana yang belum memadai menyebabkan pelaksaan GLS belum maksimal.

Program Gerakan Literasi Sekolah juga dilaksanakan di SD Negeri 1 Penatih. Namun, berdasarkan observasi yang telah dilakukan, Program Gerakan Literasi Sekolah yang dilaksanakan di SD Negeri I Penatih tahun pelajaran $2019 / 2020$ belum berjalan sesuai dengan panduan dari direktorat jenderal pendidikan dasar dan menengah Kementerian Pendidikan dan Kebudayaan.
Berdasarkan pengamatan, Siswasiswa di SD Negeri I Penatih terlihat belum terbiasa dengan kegiatan membaca. Setiap ada pembelajaran yang berkaitan dengan membaca buku, siswa terlihat kurang antusias dan tidak bersemangat dalam belajar. Permasalahan ini berdampak negatif terhadap hasil belajar yang dicapai siswa. Berdasarkan informasi dari guru hasil belajar Bahasa Indonesia khususnya siswa kelas IV sangat rendah. Hal ini terbukti dari adanya beberapa siswa yang tidak memenuhi Kriteria Ketuntasan Minimal (KKM) yang telah ditetapkan oleh sekolah.

Adapun faktor penyebab rendahnya minat baca dan hasil belajar Bahasa Indonesia siswa adalah: 1) siswa belum terbiasa untuk membaca, 2) siswa cenderung lebih senang menonton daripada membaca buku, 3) Bacaan yang dimiliki siswa masih sangat terbatas, dan 4) waktu luang siswa lebih banyak digunakan untuk bermain Gadget untuk bermedia sosial dari pada membaca artikel atau mencari pengetahuan di internet.

Mengatasi permasalahan di atas, pada penelitian ini mengoptimalkan kembali Gerakan Literasi Sekolah di SD Negeri I Penatih tahun pelajaran 2019/2020. Berdasarkan hal tersebut, maka pada penelitian ini akan mengambil judul tentang Pengaruh Gerakan Literasi Sekolah (GLS) Terhadap Minat Baca Dan Hasil Belajar Bahasa Indonesia Siswa Kelas IV SD Negeri I Penatih Tahun Pelajaran 2019/2020.

\section{METODE}

Jenis penelitian ini adalah penelitian eksperimen semu (quasy exsperiment). Salah satu ciri penting suatu eksperimen adalah pengelompokan secara random, sehingga hubungan kausal yang terjadi memang disebabkan oleh adanya perlakukan, bukan oleh faktor lain (Dantes, 2012; 94). Dengan demikian, sampel dipilih secara random untuk menentukan kelas eksperimen dan kelas kontrol. Peneliti tidak mungkin mengubah kelas dalam menentukan subjek atau 
kelas untuk kedua pembelajaran yaitu pembelajaran dengan menerapkan pembelajaran yang menerapkan Gerakan Literasi Sekolah (GLS) dan pembelajaran konvensional. Rancangan penelitian yang digunakan adalah the posttest-only control-group desain.

Populasi menurut Sugiyono (2012:61) adalah wilayah generalisasi yang terdiri atas objek atau subjek yang mempunyai kualitas dan karakteristik tertentu yang diterapkan peneliti untuk dipelajari dan kemudian ditarik kesimpulannya. Sedangkan menurut Dantes, (2012:37) populasi adalah sejumlah kasus atau sejumlah indvidu (yang sifatnya bisa infinite atau definite) yang memiliki karakteristik tertentu, maka suatu penelitian yang meneliti seluruh indvidu yang terdapat dalam wilayah penelitian dapat disebut dengan studi sensus (census study). Jadi dapat disimpulkan bahwa populasi adalah keseluruhan dari anggota kumpulan yang ingin diamati atau diteliti. Dalam penelitian ini yang menjadi populasi adalah siswa kelas IV SD Negeri I Penatih Tahun Pelajaran 2019/2020.

Teknik yang digunakan dalam pengambilan sampel ini adalah teknik sampling Teknik ini dilakukan dengan mengambil dua kelas secara acak. Random sampling dilakukan pada kelas sebagai intax group yaitu seluruh populasi yang ada di kelas eksperimen diberikan perlakuan (Dantes 2017) sesuai dengan pendapat tersebut maka peneliti memberikan perlakuan yang berkaitan dengan GLS pada seluruh siswa dalam kelas eksperimen. Pengambilan dua kelas secara acak dilakukan setelah melakukan uji kesetaraan terhadap seluruh kelas terlebih dahulu. Uji kesetaraan yang dilakukan menggunakan analisis uji $t$ dengan bantuan SPSS 17.0 for windows dengan signifikansi 5\%. Jika angka signifikansi hitung kurang dari 0,05 maka kelas tersebut tidak setara. Sedangkan jika angka signifikansi hitung lebih besar dari 0,05 maka kelas tersebut setara.

Berdasarkan uji kesetaraan menggunakan uji $t$ sebesar 0,602 sehingga di atas 0,05. Hasil ini mengindikasikan bahwa sampel pada penelitian ini memiliki kemampuan yang setara. Selanjutnya, dilakukan pemilihan sampel penelitian dengan menggunakan teknik undian. Dari teknik undian yang telah dilakukan didapatkan bahwa kelas IV A sebagai kelompok eksperimen, sedangkan kelas IV B sebagai kelompok kontrol.

Variabel bebas dalam penelitian ini adalah pembelajaran yang menerapkan Gerakan Literasi Sekolah (GLS) dan pembelajaran konvensional. Sedangkan variabel terikat dalam penelitian ini adalah minat baca dan hasil belajar siswa.

Gerakan literasi sekolah pada penelitian ini adalah pembiasaan membaca siswa. Pembiasaan ini dilakukan dengan kegiatan 15 menit membaca (guru membacakan buku dan warga sekolah membaca dalam hati, yang disesuaikan dengan konteks atau target sekolah). Ketika pembiasaan membaca terbentuk, selanjutnya akan diarahkan ke tahap pengembangan, dan pembelajaran.

Pengukuran minat baca siswa pada penelitian ini menggunakan gabungan teori dari beberapa ahli. Adapun indikator yang digunakan untuk mengukur minat baca tersebut adalah: 1) Perasaan senang membaca. 2) Kebutuhan terhadap bacaan. 3) Ketertarikan terhadap bacaan. 4) Pemanfaatan waktu. 5) Keinginan mencari bahan bacaan.

Pada penelitian ini hasil belajar adalah skor yang diperoleh siswa setelah mengerjakan sebuah tes hasil belajar. Tes hasil belajar yang dibuat berbentuk tes pilihan ganda dengan empat pilihan. Skor yang didapatkan berbentuk dikotomi yakni apabila siswa menjawab benar mendapatkan skor 1 dan apabila siswa menjawab salah mendapatkan skor 0 .

Pengumpulan data mengenai minat baca siswa dalam pembelajaran dikumpulkan menggunakan lembar kuesioner minat baca siswa. Sedangkan data mengenai hasil belajar dikumpulkan dengan memberikan tes pilihan ganda dengan empat pilihan (option).

Setelah data pada penelitian ini terkumpul, dilanjutkan dengan analisis data hasil penelitian. Hasil penelitian 
dianalisis secara bertahap, yaitu: deskripsi data, uji prasyarat, dan uji hipotesis menggunakan Manova. Seluruh analisis dalam penelitian ini menggunakan bantuan program SPSS-17.00 for windows.
1) Pengaruh Gerakan Literasi Sekolah (GLS) terhadap Minat Baca Bahasa Indonesia

Berdasarkan pengujian hipotesis pertama didapatkan hasil seperti tabel 01 di bawah ini.

\section{HASIL DAN PEMBAHASAN}

Tabel 1. Rangkuman Uji Hipotesis Pertama

\begin{tabular}{ccccccc}
\hline $\begin{array}{c}\text { Variabel } \\
\text { Terikat }\end{array}$ & Sumber & JK & Df & RJK & F & Sig. \\
\hline \multirow{3}{*}{ Minat baca } & Antar & 2070,250 & 1 & 2070,250 & 116,290 & 0,000 \\
& Dalam & 1103,750 & 62 & 17,802 & & \\
& Total & 1076470 & 64 & & & \\
\hline
\end{tabular}

Berdasarkan tabel 01 di atas, variabel minat baca memiliki nilai $F$ sebesar 116,290 dengan $p<0,05$. Ini menunjukan bahwa nilai $F$ pada variabel terikat minat baca signifikan. Maka dari itu, dapat disimpulkan bahwa terdapat perbedaan minat baca yang signifikan antara kelompok siswa yang mengikuti Gerakan Literasi Sekolah dengan kelompok siswa yang mengikuti pembelajaran konvensional.

Hasil penelitian ini sejalan dengan hasil penelitian yang dilakukan oleh Anjani (2019) dengan judul Pengaruh Implementasi Gerakan Literasi Sekolah Terhadap Minat Baca Dan Kemampuan Membaca Pemahaman Siswa Kelas V SD Gugus II Kuta Utara. Hasil analisis menunjukkan bahwa:(1) terdapat pengaruh implementasi gerakan literasi sekolah terhadap minat baca siswa kelas V SD Gugus II Kuta Utara;(2) terdapat pengaruh implementasi gerakan literasi sekolah terhadap kemampuan membaca pemahaman siswa kelas SD Gugus II Kuta Utara;(3) terdapat pengaruh secara simultan implementasi gerakan literasi sekolah terhadap minat baca dan kemampuan membaca pemahaman siswa kelas V SD Gugus II Kuta Utara.

Selanjutnya penelitian Zikra (2018) yang berjudul Pengaruh Gerakan Literasi Sekolah (GLS) Terhadap Peningkatan Minat Baca Siswa di SMAN 3 Takengon. Hasil uji $F$ terbukti bahwa F hitung 33,464 $>\mathrm{F}$ tabel 0,2199, maka hipotesis alternatif
(Ha) diterima dan hipotesis nol $(\mathrm{H} 0)$ ditolak.Dengan demikian, dapat dinyatakan bahwa Gerakan Literasi Sekolah (GLS) memliliki sedikit pengaruh terhadap peningkatan minat baca siswa. Sedangakan hasil koefisien determinasi sebesar 0,300 menunjukkan bahwa variabel independen mempengaruhi variabel dependen sebesar $30 \%$.

Selanjutnya penelitian yang dilakukan oleh Ridwan Santoso, Berchah Pitoewas, Yunisca Nurmalisa, (2018) yang berjudul Pengaruh Program Literasi Sekolah Terhadap Minat Baca Peserta Didik SMAN 2 Gadingrejo. Hasil penelitiannya diketahui bahwa terdapat pengaruh yang kuat dan signifikan antara pelaksanaan gerakan literasi sekolah dengan peningkatan minat baca peserta didik di SMA Negeri 2 Gadingrejo tahun pelajaran $2017 / 2018$. Artinya semakin baik pelaksanaan gerakan literasi sekolahnya maka akan semakin positif peningkatan minat baca peserta didik.

Gerakan Literasi Sekolah adalah gerakan sosial dengan dukungan kolaboratif berbagai elemen. Upaya yang ditempuh untuk mewujudkannya berupa pembiasaan membaca peserta didik. Pembiasaan ini dilakukan dengan kegiatan 15 menit membaca (guru membacakan buku dan warga sekolah membaca dalam hati, yang disesuaikan dengan konteks atau target sekolah). Ketika pembiasaan membaca terbentuk, selanjutnya akan diarahkan ke tahap 
pengembangan, dan pembelajaran. Keunggulan dari Gerakan Literasi Sekolah adalah mampu: 1) menambah perbendaharaan kata (kosa kata) siswa, 2) mengoptimalkan kinerja otak siswa karena sering digunakan untuk kegiatan membaca dan menulis, 3) siswa mendapat berbagai wawasan dan informasi baru, 4) kemampuan interpersonal siswa akan semakin baik, dan 5) kemampuan siswa dalam memahami makna suatu informasi akan semakin meningkat.

Adanya pembiasaan membaca peserta didik setiap hari, tentunya akan berdampak positif terhadap peningkatkan minat baca siswa. Minat baca adalah keinginan dan kemauan kuat untuk selalu membaca setiap ada kesempatan atau selalu mencari kesempatan untuk membaca dengan tujuan menambah pengetahuan. Ciri orang yang mempunyai minat baca yang tinggi diantaranya selalu memanfaatkan waktu luang untuk membaca, dan melakukan kegiatan membaca dengan senang hati Pemeliharaan minat baca perlu dilakukan secara terus menerus dengan selalu berupaya meningkatkan ketrampilan membaca secara memadai. Untuk itulah perlu dilakukan upaya yang mampu mendorong motivasi siswa untuk membaca.

Gerakan Literasi Sekolah pada penelitian ini menyebabkan adanya perubahan dari kemampuan dan kemauan siswa dalam hal membaca. Sejak diterapkan Gerakan Literasi Sekolah, siswa menjadi antusias dalam membaca, bacaan yang dibacanya pun sangat beragam. Siswa sering membaca di pojok baca Siswa terlihat senang dan tidak merasa terbebani dalam kegiatan membaca,dari bacaan yang dibaca, siswa dapat menjelaskan isi bacaan kepada teman-temannya bahkan sudah berani mendongeng di depan kelas menghibur temannya bahkan memperagakan gerakan-gerakan tokoh yang terdapat pada cerita yang dibaca, sehingga pembelajaran berjalan dengan sangat menyenangkan. Hal ini menunjukkan bahwa minat baca siswa menjadi meningkat sejak diterapkannya Gerakan Literasi Sekolah.

Berdasarkan pemaparan di atas, dapat disimpulkan bahwa terdapat pengaruh Gerakan Literasi Sekolah (GLS) terhadap Minat Baca Bahasa Indonesia pada Siswa Kelas IV SD Negeri I Penatih Kecamatan Denpasar Timur Tahun Pelajaran 2019/2020.

2) Pengaruh Gerakan Literasi Sekolah (GLS) terhadap Hasil Belajar Bahasa Indonesia

Berdasarkan pengujian hipotesis kedua didapatkan hasil seperti tabel 02 di bawah ini.

Tabel 2. Rangkuman Uji Hipotesis Kedua

\begin{tabular}{ccccccc}
\hline $\begin{array}{c}\text { Variabel } \\
\text { Terikat }\end{array}$ & Sumber & JK & Df & RJK & F & Sig. \\
\hline $\begin{array}{c}\text { Hasil } \\
\text { belajar }\end{array}$ & Antar & 558,141 & 1 & 558,141 & 63,499 & 0,000 \\
bahasa & Dalam & 544,969 & 62 & 8,790 & & \\
indonesia & Total & 32565 & 64 & & & \\
\hline
\end{tabular}

Berdasarkan tabel 02 di atas, variabel hasil belajar Bahasa Indonesia memiliki nilai $F$ sebesar 63,499 dengan $p<0,05$. Ini menunjukan bahwa nilai $F$ pada variabel terikat hasil belajar Bahasa Indonesia signifikan. Maka dari itu, dapat disimpulkan bahwa terdapat perbedaan hasil belajar Bahasa Indonesia yang signifikan antara kelompok siswa yang mengikuti Gerakan Literasi Sekolah dengan kelompok siswa yang mengikuti pembelajaran konvensional.

Hasil penelitian ini diperkuat dari penelitian yang dilakukan oleh Annika Bergbauer dan Surette van Staden (2018) yang berjudul Social Interaction 
Determinants of South African Reading Literacy Achievement:Evidence from prePIRLS 2011 (Penentu Interaksi Sosial Prestasi Baca Baca Afrika Selatan: Bukti dari prePIRLS 2011). Dalam penelitiannya dinyatakan bahwa: Temuan menjelaskan $41 \%$ dari varians dalam prestasi membaca siswa dan memberikan bukti untuk peran penting dari guru dan orang tua dalam memprediksi peningkatan skor prestasi baca tulis. Tidak adanya interaksi dengan anak di kedua orang tua yang tidak terlibat dalam kegiatan pekerjaan rumah atau berbicara tentang sekolah, guru yang tidak berhasil menerapkan kurikulum atau membuat harapan mereka jelas bagi siswa menghubungkan secara statistik secara signifikan dengan skor pencapaian membaca literasi yang lebih rendah. Prestasi untuk siswa kelas 4 yang diuji dalam bahasa Afrika lebih buruk daripada siswa yang menggunakan tes bahasa.

Selanjtunya penelitian yang dilakukan oleh Juniawan (2020) dengan judul Pengaruh Pembelajaran Saintifik Berbasis Literasi Terhadap Kemampuan Membaca Pemahaman Dan Hasil Belajar Pelajaran Kelompok Sosial Humaniora Siswa Kelas V SD di Gugus 1 Kuta. Hasil menunjukkan bahwa terdapat perbedaan kemampuan membaca pemahaman dan perbedaan hasil belajar mata pelajaran kelompok sosial humaniora serta terdapat perbedaan secara simultan terhadap kemampuan membaca pemahaman dan hasil belajar mata pelajaran kelompok sosial humaniora antara kelas eksperimen dengan kelas kontrol.

Hasil belajar merupakan bentuk perubahan prilaku yang cenderung menetap dari ranah Kognitif, Afektif, dan Psikomotorik dari proses belajar yang dilakukan dalam waktu tertentu. Salah satu upaya untuk meningkatkan hasil belajar siswa adalah dengan membiasakan siswa membaca setiap hari. Gerakan pembiasaan membaca di sekolah dinamakan gerakan literasi sekolah. Tujuan kegiatan literasi di tahap pembiasaan adalah: 1) meningkatkan rasa cinta baca di luar jam pelajaran, 2) meningkatkan kemampuan memahami bacaan, 3) meningkatkan rasa percaya diri sebagai pembaca yang baik; dan 4) menumbuh kembangkan penggunaan berbagai sumber bacaan.Dengan terbiasanya siswa membaca, tentunya membuat wawasan siswa menjadi luas dan hasil belajar siswa pun dapat ditingkatkan.

Menurut Panduan Gerakan Literasi sekolah di sekolah Dasar (2016: 2) Gerakan Literasi Sekolah mempunyai dua tujuan, yaitu tujuan umumnya adalah menumbuh kembangkan budi pekerti peserta didik melalui pembudayaan literasi sekolah yang diwujudkan dalam Gerakan Literasi Sekolah agar mereka menjadi pembelajar sepanjang hayat. Sedangkan tujuan khususnya adalah: 1) menumbuh kembangkan budaya literasi di sekolah, 2) meningkatkan kapasitas warga dan lingkungan sekolah agar literat, 3) menjadikan sekolah sebagai taman belajar yang menyenangkan dan ramah anak agar warga sekolah mampu mengelola pengetahuan, dan 4) menjaga keberlanjutan pembelajaran dengan menghadirkan beragam buku bacaan dan mewadahi berbagai strategi membaca.

Dari penelitian yang telah dilakukan dengan menerapkan Gerakan Literasi Sekolah siswa, wawasan siswa terlihat lebih meningkat daripada sebelum diterapkan Gerakan Literasi Sekolah. Hal ini dikarenakan dalam kegiatan membaca secara tidak langsung kemampuan siswa terasah, wawasan menjadi lebih luas, dan membuat rasa ingin tahu siswa menjadi lebih tinggi. Hal ini menyebabkan siswa semakin banyak bertanya tentang hal-hal baru yang dibacanya. Kegiatan seperti itu menyebabkan pengetahuan siswa menjadi bertambah pesat, sehingga berdampak positif terhadap peningkatan hasil belajar siswa di sekolah.

Berdasarkan pemaparan di atas, dapat disimpulkan bahwa terdapat pengaruh Gerakan Literasi Sekolah (GLS) terhadap hasil belajar Bahasa Indonesia siswa pada kelas IV SD Negeri I Penatih Kecamatan Denpasar TimurTahun Pelajaran 2019/2020. 
3) Pengaruh Gerakan Literasi Sekolah (GLS) terhadap Minat Baca dan Hasil Belajar Bahasa Indonesia
Berdasarkan pengujian hipotesis ketiga, didapatkan hasil seperti tabel $03 \mathrm{di}$ bawah ini.

Tabel 3. Rangkuman Uji Hipotesis Ketiga

\begin{tabular}{lccc}
\hline \multicolumn{1}{c}{ Statistik } & Nilai F & Taraf Signifikansi (sig.) & Kesimpulan \\
\hline Pillai's Trace & 79,658 & 0,000 & Signifikan \\
Wilks' Lambda & 79,658 & 0,000 & Signifikan \\
Hotelling's Trace & 79,658 & 0,000 & Signifikan \\
Roy's Largest Root & 79,658 & 0,000 & Signifikan \\
\hline
\end{tabular}

Berdasarkan tabel 03 di atas, variabel F untuk Pillai's Trace, Wilks' Lambda, Hotelling's Trace, dan Roy's Largest Root memiliki nilai $\mathrm{F}$ hitung sebesar 79,658 dengan $p<0,05$. Maka dari itu, dapat disimpulkan bahwa terdapat perbedaan minat baca dan hasil belajar Bahasa Indonesia yang signifikan antara kelompok siswa yang mengikuti Gerakan Literasi Sekolah dengan kelompok siswa yang pembelajaran konvensional Sebelum mengikuti pembelajaran dengan menerapka GLS,kemauan peserta didik untuk membaca dipojok baca tidak tampak mereka hanya membaca ketika guru menyuruh,begitupula dalam kegiatan membaca 15 menit sebelum pembelajaran dimulai terlebih dahulu guru menyuruh murid membaca bahan bacaan dan guru mengawasi dari depan kelas. Ketika pembelajaran berlangsung guru menyuruh peserta didik membaca secara bergilir setelah beberapa orang membaca guru baru memulai kegiatan pembelajaran melihat situasi seperti ini akan mempengaruhi alokasi waktu pada penyampaian inti pembelajaran,pada waktu pembelajaran mengarang peserta didik menyelesaikan karangannya tidak sesuai dengan waktu yang ditetapkan oleh guru, hal ini disebabkan karena pembendaharaan kata pada peserta didik sangat minim akibat kurangnya minat baca pada bahan bacaan. Pada pembelajaran menentukan amanat dalam sebuah cerita baik fiksi maupun non fiksi peserta didik belum mampu menjelaskan secara mendetail. Setelah diterapkan Gerakan Literasi Sekolah Siswa sudah aktif dalam membaca, guru tidak lagi mengingatkan siswa untuk membaca, kegiatan membaca 15 menit berjalan lancar,siswa aktif membaca di pojok baca, siswa mampu menyelesaikan tugas yang diberikan oleh guru tepat waktu, siswa mampu menyebutkan tokoh,karakter, amanat,dan unsur-unsur cerita,siswa mampu mendongeng di depan kelas,nilai Bahasa Indonesia meningkat.

Gerakan Literasi Sekolah adalah Suatu gerakan yang melibatkan semua warga sekolah (guru, peserta didik, orangtua/wali murid) dan masyarakat, yang bertujuan untuk mebiasakan membaca dan meningkatkan pengetahuan. Gerakan literasi yang mencakup sekolah, keluarga, dan masyarakat ini diawali dengan menumbuhkan minat baca pada peserta didik membiasakan untuk membaca meningkatkan keterampilan membaca trampil menggunakan berbagai media dengan tujuan untuk meningkatkan pengetahuan

Dari pemaparan di atas terlihat bahwa Gerakan Literasi Sekolah mampu menumbuhkan minat baca siswa. Setelah minat baca siswa meningkat, maka membuat siswa ketagihan untuk membaca dan wawasan siswapun bertambah menjadi luas. Luasnya wawasan, membuat siswa mudah memahami materi pelajaran, sehingga hasil belajar siswa pun dapat ditingkatkan.

Berdasarkan hal tersebut maka dapat disimpulkan bahwa terdapat pengaruh Gerakan Literasi Sekolah (GLS) terhadap minat baca dan hasil belajar Bahasa Indonesia pada Siswa Kelas IV SD Negeri I Penatih Kecamatan Denpasar Timur Tahun Pelajaran 2019/2020.

Implikasi dari pelaksanaan Gerakan Literasi Sekolah adalah pertama, dengan 
melaksanakan Gerakan Literasi Sekolah siswa menjadi terbiasa dan gemar membaca. Kebiasaan ini menunjukkan bahwa minat baca siswa sudah tergolong sangat tinggi. Kedua, dengan terbiasanya siswa dalam membaca membuat wawasan siswa menjadi bertambah. Hal ini berdampak positif terhadap kemampuan siswa dalam menyelesaikan permasalahan dalam pembelajaran, sehingga hasil belajar siswa pun dapat ditingkatkan. Ketiga, dengan melaksanakan Gerakan Literasi Sekolah siswa menjadi lebih bijak dalam memanfaatkan teknologi infomasi dan komunikasi. Dikarenakan siswa tidak hanya menggunakan gadgetnya untuk mengakses media sosial saja, namun juga mengakses bacaan-bacaan yang menunjang dalam pembelajaran.

\section{PENUTUP}

Berdasarkan hasil pengujian hipotesis dan pembahasan di atas dapat disimpulkan bahwa: terdapat pengaruh yang signifikan Gerakan Literasi Sekolah (GLS) terhadap minat baca Bahasa Indonesia pada siswa kelas IV SD Negeri I Penatih Kecamatan Denpasar Timur Tahun Pelajaran 2019/2020. Hal ini terlihat dari $F$ hitung sebesar 116,290 dan signifikansi dengan $p<0,05$, terdapat pengaruh yang signifikan Gerakan Literasi Sekolah (GLS) terhadap hasil belajar Bahasa Indonesia pada siswa kelas IV SD Negeri I Penatih Kecamatan Denpasar Timur Tahun Pelajaran 2019/2020.Hal ini terlihat dari $F$ hitung sebesar 63,499 dan signifikansi dengan $p<0,05$, terdapat pengaruh yang signifikan Gerakan Literasi Sekolah (GLS) terhadap minat baca dan hasil belajar Bahasa Indonesia pada siswa kelas IV SD Negeri I Penatih Kecamatan Denpasar Tahun Pelajaran 2019/2020. $\mathrm{Hal}$ ini terlihat dari $\mathrm{F}$ hitung sebesar 79,658dan signifikansi dengan $p<0,05$. Berdasarkan simpulan yang telah dipaparkan dapat disampaikan saran bahwa: guru disarankan untuk selalu memperhatikan frekuensi kegiatan membaca siswa, karena semakin sering siswa membaca maka kegiatan membaca semakin melekat dalam diri siswa, dan siswa pun merasa tidak berbebani dalam membaca. Hal ini akan berdampak positif terhadap capaian hasil belajar siswa di sekolah.

\section{DAFTAR RUJUKAN}

Abidin, Yunus. Dkk. 2017. Pembelajaran Literasi. Jakarta. Bumi Aksara.

Anjani, Sri. 2019. Pengaruh Implementasi Gerakan Literasi Sekolah Terhadap Minat Baca Dan Kemampuan Membaca Pemahaman Siswa Kelas V SD Gugus II Kuta Utara. E-Jurnal Pendasi: Jurnal Pendidikan Dasar Indonesia. Volume 3 No 2.

Bergbauer, Annika dan Surette van Staden. 2018. Social Interaction Determinants of South African Reading Literacy Achievement: Evidence from prePIRLS 2011. International Journal of Instruction April2018, Vol.11,No.2e-ISSN: 1308-1470, www.e-iji.netp-ISSN: 1694-609X.

Dantes, Nyoman. 2012. Metode Penelitian. Yogyakarta; Andi.

Dantes, Nyoman. 2017. Pedagogik Dalam Perspektif. Singaraja; Undiksha Press.

Direktorat Jendral Pendidikan Dasar dan Menengah, Kementrian Pendidikan dan Kebudayaan Republik Indonesia. 2016. Panduan Gerakan Literasi di Sekolah Menengah Atas, tersedia http://dikdas.kemdikbud.go.id/wpcontent/uploads/2016/04/PanduanGerakan-Literasi-Sekolah-diSMA.pdf, diunduh pada 10 Januari 2017.

Faradina, Nindya. 2017. Pengaruh Program Gerakan Literasi Sekolah Terhadap Minat Baca Siswa Di Sd Islam Terpadu Muhammadiyah AnNajahJatinom Klaten. Jurnal Hanata Widya Volume 6 Nomor 8.

Juniawan, Made Edy. 2020. Pengaruh Pembelajaran Saintifik Berbasis Literasi Terhadap Kemampuan Membaca Pemahaman Dan Hasil 
Belajar Pelajaran Kelompok Sosial Humaniora Siswa Kelas V SD di Gugus 1 Kuta. E-Jurnal Pendasi: Jurnal Pendidikan Dasar Indonesia. Volume 4 No 1.

Kalida dan Mursyid. 2015. Gerakan Literasi Mencerdaskan Negeri. Yogyakarta: Aswaja Presindo.

PISA .2015.Result in Focus. 2016, tersedia dari https://www.oecd.org/pisa/keyfinding s/pisa-2012-results-overview.pdf, diunduh pada 13 Januari 2017.

Santoso, Ridwan, Berchah Pitoewas, dan Yunisca Nurmalisa. 2018. Pengaruh Program Literasi Sekolah Terhadap Minat Baca Peserta Didik SMAN 2 Gadingrejo. Jurnal Kultur Demokrasi Volume 5 Nomor 9.

Sugiyono. 2012. Metode Penelitian Pendidikan, Pendekatan Kuantitatif, Kualitatif, dan $R$ \& $D$. Bandung; Alfabeta.

Suyono dan Hariyanto. 2011. Belajar dan Pembelajaran. Bandung : PTRemaja Rosdakarya.

Zikra, Sari Dariska Zikrayanti Sari. 2018. Pengaruh Gerakan Literasi Sekolah (GLS) Terhadap Peningkatan Minat Baca Siswa di SMAN 3 Takengon. Jurnal LIBRIA Volume 10 Nomor 2. 